\title{
OSOBA JEZUSA CHRYSTUSA I JEJ UNIWERSALNE ZNACZENIE Perspektywa patrystyczna
}

W stosunku do Ojców Kościoła w dzisiejszej teologii można odnotować swoiste napięcie. Z jednej strony, nie ulega wątpliwości, zauważa się i akcentuje ich „aktualność”. Jednak równocześnie, z drugiej strony, ich świadectwo jest mocno krytykowane i eliminowane ze współczesnej świadomości kulturowej ${ }^{1}$. W tym drugim nurcie warto zwrócić uwagę na dwa fakty. Po pierwsze, proponowane dzisiaj $\mathrm{z}$ naciskiem historyczne metody badawcze, stosowane w odniesieniu do Ojców Kościoła, które opierają się na jednostronnym historyzmie, faktycznie pomijającym, a nawet eliminującym kwestię prawdy, zamykają ich w odległej przeszłości. Takie podejście metodologiczne sprawia, że tracą oni wyraźnie na aktualności, ponieważ nie mają nic do powiedzenia dzisiejszemu człowiekowi i wierzącemu, skoro ich wymowa jest tylko historyczna. Po drugie, możemy zauważyć jak dzisiaj faktycznie eliminuje się problematykę patrystyczną i teologię Ojców z curriculum studiów teologicznych, zastępując tę ważną dyscyplinę teologiczną jakimiś dyscyplinami, które ocierają się o psychologię bądź socjologię w imię tak zwanej „praktyczności” teologii. Nie jest to nic innego, jak poddanie studiów teologii naciskowi mody i ideologii.

W niniejszym artykule zamierzam zwrócić uwagę na Ojców Kościoła i ich aktualność, biorąc za przykład ich chrystologię, która odznacza się szczególną integralnością doktrynalną i nośnością egzystencjalną, a więc tymi przymiotami, na które szczególnie zwrócono uwagę w teologii ostatnich dziesięcioleci, starając się pokazać znaczenie tajemnicy Jezusa Chrystusa dla dzisiejszego człowieka. Formułowane propozycje teologiczne, niejednokrotnie zdecydowanie zrywające $\mathrm{z}$ tradycją wiary Kościoła i kierujące się arbitralnymi założeniami, nie tylko nie zbliżyły ludzi do tajemnicy Jezusa Chrystusa, ale ich od niej oddaliły. Wobec zamętu istniejącego w dzisiejszej chrystologii, która gubi się

${ }^{1}$ Wśród najnowszych wypowiedzi na temat aktualności Ojców Kościoła, por. Les Pères de l'Église dans le monde d'aujourd'hui. Actes du colloque international organise par le New Europe College en collaboration avec Ludwig Boltzmann Gesellschaft (Bucarest, 7-8 octobre 2004), red. C. Badilita - Ch. Kannengieser, Paris 2006; „De commencement en commencement”. Le renouveau patristique dans le théologie contemporaine, red. Y.M. Blanchard - G. Bardy, Paris 2007. 
w swoich poszukiwaniach, warto więc zapytać się Ojców Kościoła o strukturę, jaką nadali swojej chrystologii, prezentując ją ludziom swoich czasów i czyniąc ją czytelną dla ich wymagań egzystencjalnych. Argumentem praktycznym przemawiającym za potrzebą podjęcia takich poszukiwań jest fakt, że najbardziej znaczące propozycje chrystologiczne, które sformułowano w XX wieku, miały głębokie zakorzenienie w Ojcach Kościoła ${ }^{2}$.

\section{STRUKTURA CHRYSTOLOGII PATRYSTYCZNEJ}

W epoce patrystycznej zainteresowanie teologii i soborów powoli skoncentrowało się na problemie „struktury” (= „kompozycji”) osoby Jezusa Chrystusa w podwójnym znaczeniu: w odniesieniu do Jego człowieczeństwa (ciało - dusza - rozum) i w odniesieniu do Jego osoby (człowieczeństwo - bóstwo). Gdy w chrystologii mówi się o zjawisku ontologizacji chrystologii, to przez to stwierdzenie rozumie się uwypuklenie właśnie tego faktu. Autorzy widzący moment negatywny w ramach tego ujęcia, stwierdzają, że wymiar strukturalny, czyli dotyczący bytu Jezusa Chrystusa, zyskał w ten sposób pierwszeństwo w stosunku do wymiaru dynamicznego, czyli historycznego, dotyczącego Jego zbawczego działania, a tym samym ulega pomniejszeniu kwestia soteriologiczna. Zwracając natomiast uwagę, że ta preferencja odzwierciedla ukierunkowanie myśli greckiej, mówi się także o „,hellenizacji” chrystologii. Tak przedstawiany Jezus miałby stać się „Grekiem pośród Greków”3.

Jeśli zatrzymać się na takich stwierdzeniach (jak czyni wielu współczesnych badaczy), to jednak nie chwyta się całego Chrystusa Ojców, ale tylko Jego część; chwyta się to, co zawierające (forma), ale nie to, co zawarte (treść). Duszą, która ożywia tę strukturę, jest bowiem uniwersalne znaczenie osoby Jezusa Chrystusa. Ówczesna teologia nie badała tak gorliwie Jego „,bytu” w innym celu, jak tylko po to, by uchwycić Jego „znaczenie”. Czy zdołała to osiągnąć? Wydaje się, że w wyjątkowym stopniu, chociaż należy zauważyć, że całość była formułowana w odniesieniu do tamtej chwili historycznej i tamtej kultury, dlatego nie jest powiedziane, że zostało wyczerpane to wszystko, co można powiedzieć o znaczeniu Jezusa Chrystusa dla każdej epoki i każdej kultury.

Aby pokazać strukturę chrystologii Ojców Kościoła, zostaną tutaj wyróżnione trzy dziedziny relacji, w których starożytni teologowie dokonali odkrycia znaczenia Jezusa Chrystusa i zaproponowania go ludziom swoich czasów.

${ }^{2}$ Por. V. Holzer, Les traits contemporaines de christologie et leurs sources patristique, w: „De commencement en commencement", s. 229-245.

${ }^{3}$ O świadomości Ojców Kościoła, dotyczącej niebezpieczeństwa hellenizacji orędzia chrześcijańskiego i sposobach jej unikania, por. C. Micaelli, La cristianizzazione dell'ellenismo, Brescia 2005. 
Te dziedziny pokażą sposób ujmowania tajemnicy chrystologicznej, który zachowuje swoją aktualność także w odniesieniu do naszych czasów.

1. Chrystus interesuje całego człowieka. Ojcowie Kościoła wychodzili przede wszystkim od przyjęcia, że istnieje bardzo ścisły związek między wymiarem ontologicznym tajemnicy chrystologicznej: Chrystus przyjąt całego człowieka, z jej wymiarem soteriologicznym: Chrystus zbawia całego człowieka. Stwierdza Orygenes:

„Nie zostałby zbawiony cały człowiek, gdyby [Chrystus] nie przyjął całego człowieka" ${ }^{4}$.

Fakt, że Chrystus jest człowiekiem integralnym sprawia, że ma On znaczenie w stosunku do całego człowieka, a więc nie tylko dla jego ducha, lecz także dla jego ciała ${ }^{5}$, nie tylko dla życia wiecznego, lecz także dla jego życia i jego działania historycznego w tym świecie. Stad też chrystologia wpłynęła na przykład na ukształtowanie się nowej teorii poznania oraz uwypukliła „polityczne” znaczenie Ewangelii. Wcielenie stanowi podstawę do podjęcia przez chrześcijanina zadań w stosunku do kultury, cywilizacji, czy promocji ludzkiej. Nie chodzi zresztą o jakiekolwiek zbawienie, rozumiane, na przykład, jako ucieczka od świata (fuga mundi), ale o zbawienie w sensie najpełniejszym, spójnym, obejmującym zarówno jego moment negatywny, a więc autentyczne wyzwolenie, jak również jego moment pozytywny, to znaczy wspólnotę z Bogiem. „Wszyscy jesteśmy wolni w Chrystusie!”, wołał pewien autor z II wieku. Grzegorz z Nazjanzu stwierdzał:

„Co nie zostało przyjęte, to nie zostało uzdrowione, ale to, co zostało zjednoczone z Bogiem, jest zbawione"

A szczytem zbawienia jest przebóstwienie:

„Bóg stał się człowiekiem, aby człowiek stał się Bogiem”7 .

To podstawowe znaczenie wcielenia Syna Bożego jest spokojnie przyjęte w całej chrystologii patrystycznej, która zawiera zasadniczy wymiar soteriologiczny. Ojcom jest obca wszelka dychotomia między ontologią i soteriologią w tajemnicy Jezusa Chrystusa. Obydwa aspekty tej tajemnicy stanowią jedną, nierozerwalną całość na zasadzie zachodzącej między nimi „wewnętrznej wy-

${ }^{4}$ Origenes, Disputatio cum Heracleida 7, SCh 67, 70.

${ }^{5}$ Warto zwrócić uwagę, że dla Ojców Kościoła kwestia chrystologiczna przekładała się w sposób bezpośredni na kwestię antropologiczną, której szczególnym wyrazem stała się prawda mówiąca o zmartwychwstaniu ciała, będąca jednym z ważniejszych elementów orędzia chrześcijańskiego wobec świata pogańskiego.

${ }^{6}$ Gregorius Nazianzenus, Epistula 101, 1, 32, SCh 208, 50.

7 Tamże 1, 20, SCh 208, 44. 
mienności”. Wizja ta dotyczy zarówno Ojców wschodnich, jak i zachodnich, nawet jeśli w swojej refleksji ci pierwsi bardziej koncentrują się na tajemnicy wcielenia, a ci drudzy mocniej akcentują znaczenie Misterium Paschalnego. Ogólna perspektywa ich refleksji pozostaje jednak zawsze taka sama.

2. Chrystus interesuje wszystkich ludzi. Już w Nowym Testamencie widać w sposób oczywisty, że znaczenie Jezusa Chrystusa nie wyczerpuje się w odniesieniu do narodu żydowskiego i nie zamyka w ramach jego historii, ale obejmuje wszystkie narody. Mateusz $(1,1-17)$ wyprowadza rodowód Jezusa od Abrahama, pozostającego archetypem narodu wybranego. Jednak Łukasz (3, 23-38) idzie dalej - nawiązuje w swoim rodowodzie do Adama, archetypu całej ludzkości. Św. Paweł afirmuje tę drugą linię w interpretacji Jezusa Chrystusa, rozwijając ją w temacie „nowego Adama” (1Kor 15, 45-49), to znaczy przedstawiciela i początku nowej ludzkości.

Ojcowie Kościoła, opierając się na tych danych Nowego Testamentu, podjęli znaczący wysiłek ukazania uniwersalnego znaczenia osoby Jezusa Chrystusa, także z punktu widzenia teologicznego. Początkowe dzieje teologii zostały dogłębnie naznaczone dwoma wizjami wymownie ilustrującymi kwestię uniwersalizmu chrystologicznego. Chodzi o wizje zaprezentowane przez św. Justyna i św. Ireneusza.

W poł. II wieku Justyn rozwinął zagadnienie uniwersalizmu chrystologicznego w perspektywie synchronicznej. Pokazał więc, że Jezus Chrystus ma znaczenie dla wszystkich narodów i kultur, istniejących w każdej chwili historii. Uczynił to za pośrednictwem słynnej teorii „Słowa rozproszonego” (gr.

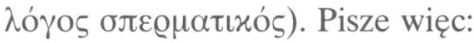

„Jest więc rzeczą oczywistą, że nauka nasza przewyższa zdecydowanie wszelką naukę ludzką z tego powodu, że cały Logos, Chrystus, który dla nas się objawił, stał się, ciałem, rozumem i duszą. Wszystko bowiem co kiedykolwiek filozofowie i prawodawcy dobrego odkryli lub wypowiedzieli, uczynili to dzięki temu, że częściowo znaleźli lub ujrzeli właśnie w Logosie" ${ }^{\text {" }}$.

\section{Z tego założenia Justyn wyprowadził zdecydowaną i mocną konkluzję:}

„Wszystko więc, co prawdziwego zostało wyrażone w ich [= filozofów] poglądach, przynależy do nas chrześcijan. My bowiem zaraz po Bogu oddajemy cześć i miłujemy Logos pochodzący od Boga niezrodzonego i niewysłowionego, gdyż dla nas On stał się człowiekiem, by mieć udział w naszych cierpieniach i je uleczyć"

Chrystus jest więc samym źródłem, z którego wypływają te krople prawdy, które stały się dostępne dla wszystkich.

\footnotetext{
${ }^{8}$ Justinus, Apologia II 10, 1-2, PG 6, 460BC, thum. L. Misiarczyk: BOK 24, 278.

${ }^{9}$ Tamże 13, 4, PG 6, 465-468, BOK 24, 281.
} 
Wszystko to, co rzeczywistość ludzka ma pozytywnego, zależy więc od Chrystusa i zmierza do Chrystusa. Zmierza do Niego historia narodu żydowskiego jak proroctwo zmierza do swojego wypetniania; zmierza do Niego historia wszystkich narodów, jak część zmierza do zjednoczenia się z całościq i nabiera sens całości. „Ziarna prawdy” zmierzają więc do całej Prawdy. Nic nie jest obce Chrystusowi; nic nie jest niezależne od Niego. Jezus odnosi się w szczególności do Żydów, ale Jego przesłanie i działanie dotyczy wszystkich. Idąc po linii Justyna można by zarysować teologię religii niechrześcijańskich, która odznaczałaby się szczególną aktualnością. Także wartości religijne, podobnie jak filozoficzne, różnych narodów mogą nabrać znaczenia przez odniesienie do Chrystusa i w jakiś sposób zmierzają do Niego. Są one wprawdzie częściowymi, ale autentycznymi elementami ludzkiego dążenia do Boga, które pewnego dnia znajdą swoje integralne usytuowanie w tej „całości”, którą jest religia chrześcijańska oparta na osobie Słowa, nie tracąc zarazem swojej własnej oryginalności ${ }^{10}$.

Inne dążenie o takim samym znaczeniu, ale bardziej ukierunkowane w sensie historycznym, czy też diachronicznym, zaprezentował św. Ireneusz z Lyonu (koniec II wieku). Oparł się on na doktrynie św. Pawła (por. Ef 1,10) dotyczącej rekapitulacji. Chrystus, przychodząc we wcieleniu, dokonał rekapitulacji (to znaczy zjednoczył, odnowił, zbawił) całą historię ludzką, od samego początku. Powracając w czasie paruzji, dokona On rekapitulacji (w sensie 1Kor 15, 24) całej nowej historii, zapoczątkowanej wraz z Jego wcieleniem: „Wszystkie języki [...] wszystkie narody i każde pokolenie"11. Chrystus niejako wziął na siebie całą historię ludzką, aby doprowadzić ją do tego celu, do którego była ona pierwotnie skierowana, to znaczy do wspólnoty z Bogiem:

„Est autem hic Verbum jus, Dominus noster Jesus Christus, qui in novissimis temporibus homo in hominibus factus est, ut finem cojungeret principio, hoc est hominem Deo"12.

Wzrost i postęp człowieka (dzisiaj można by powiedzieć ewolucja) nabierają sensu w Chrystusie, gdyż nie prowadzi On do wypełnienia historii ludzkiej w sposób niejako mechaniczny, czy też dokonując jej radykalnej metamorfozy, ale wiedzie ją do organicznej dojrzałości w sposób podobny do dojrzewania człowieka, to znaczy opierającego się na stopniowym i osobowym rozwoju, w którym dokonuje się wydobywania zawartych w niej możliwości ${ }^{13}$.

${ }^{10}$ Jeśli chodzi o szczegółowe przedstawienie wizji Justyna, por. D. Bourgeois, La sagesse des anciens dans le mystère du Verbe. Évangile et philosophie chez Saint Justin philosophe et martyr, Paris 1981.

11 Irenaeus, Adversus haereses III 22, 3, SCh 211, 438.

12 Tamże IV 20, 4, SCh 100, 634.

13 Tamże IV 38, 1, SCh 100, 946-948. 
Także Ireneusz opiera to ,znaczenie” Jezusa Chrystusa na Jego „,bycie”, to znaczy na rzeczywistości Jego wcielenia. Jego wykład zwraca się przeciw marcjonizmowi i doketyzmowi, a więc interpretacjom, które kwestionowały cielesny i historyczny wymiar tajemnicy wcielenia Słowa, czyli w gruncie rzeczy kwestionowały jego realizm, a tym samym na nowo oddzielały człowieka od wspólnoty z Bogiem ${ }^{14}$.

\title{
3. Chrystus oświeca i podtrzymuje wszechświat. Nowy Testament dostar-
} czył pewnych ważnych elementów pozwalających nadać Chrystusowi znaczenie w stosunku do kosmosu ujętego całościowo. „Wszystko przez Nie (słowo) się stało”, napisał św. Jan w Prologu (1, 3). Św. Paweł sprecyzował: „Byty widzialne i niewidzialne. [...] Wszystko przez Niego i dla Niego zostało stworzone" (Kol 1, 16). Drżenie oczekiwania, którego obecność Apostoł zauważa w całym stworzeniu (por. Rz 8, 19-22), jest czymś w rodzaju uznania tej wzajemnej przynależności Jezusa Chrystusa i kosmosu. Także stworzenie „odczuło” Jego przejście przez ziemię. Chrystus, przyodział się w świat (amictus mundo), jak mówił Pierre Teilhard de Chardin, w jakby drugie ciało (przy czym oczywiście nie chodzi o unię hipostatyczną) $)^{15}$.

Te skromne akcenty nowotestamentalne nabrały u Ojców Kościoła nadzwyczajnego znaczenia i zostały rozwinięte w sposób doskonale spójny z całością wiary. Na przykład św. Atanazy wyjaśnia:

\begin{abstract}
„Słowem więc będąc, nie jest na podobieństwo ludzkiego [...] złożone z sylab, ale swojego Ojca jest wiernym obrazem. Ludzie z części są złożeni i z nicości powstali, ich słowo jest złożone i podzielone; Bóg natomiast jest bytującym i nie złożonym, dlatego i Słowo jest bytującym i nie złożonym, który z Ojca jako dobrego źródła pochodząc, wszystko uładza i spaja. Przyczyna, z powodu której Słowo Boga rzeczywiście zstąpiło do istot stworzonych, jest naprawdę zadziwiająca, dając poznać, że nie inaczej powinno się dziać, niż jest. Natura bowiem istot stworzonych, które z nicości powstały, okazuje się dość niestabilna, słaba i śmiertelna, jeśli ją rozważać samą w sobie; jednakże Bóg wszystkiego dobry jest i przepiękny co do natury. Dlatego też jest przyjazny ludziom. «Dobrym bowiem być, to nie może mieć zawiści do nikogo»; dlatego nie zazdrości nikomu istnienia, ale chce, by wszystko było, żeby mógł okazać przyjaźń ludziom. Widząc zatem całą naturę stworzoną, jak na mocy swoich właściwości niestabilna jest i się rozpada, żeby tego nie doznała i by cały świat nie zapadł się z powrotem w nicość, z powodu swego wiecznego Słowa uczyniwszy wszystko i sprawiwszy istnienie stworzenia, nie dopuścił jego własnej naturze nieść go i gnać - żeby mu nie zagroził powrót do nicości; będąc dobry, swoim Słowem, które samo jest Bogiem, wszechświatem
\end{abstract}

${ }^{14}$ Szczegółowe omówienie propozycji Ireneusza por. w: B. Sesboüé, Tout récapituler dans le Christ. Christologie et sóteriologie d'Irénée de Lyon, Paris 2000; E. Osborn, Irenaeus of Lyon, Cambridge 2001, 97-140.

15 Jeśli chodzi o rozwój chrystologii kosmicznej, por. G.A. Maloney, Chrystus kosmiczny. Od Pawła do Teilharda, tłum. T. Mieszkowski, Warszawa 1986. 
steruje i stabilizuje go, że by Słowa zarządem, opatrznością i uładzeniem oświecone, stworzenie mogło trwać pewnie, skoro w rzeczywiście będącym z Ojca Słowie uczestniczy i wspierane jest przez nie w istnieniu, ażeby nie doznało tego, czego mogłoby doznać, gdyby Słowo go nie strzegło - mówię tu o nieistnieniu"16.

Oto, co znajduje się za definicją Soboru Nicejskiego dotyczącą „współistotności” Syna w relacji do Ojca. Nie chodzi tutaj o drętwą metafizykę - jak mówi się niejednokrotnie - ale o żywą wizję wiary. Wszechświat jest już pojmowany jako oświecony i ożywiony z wysoka (a przez wcielenie od wewnątrz) przez światło Słowa; od Niego pochodzi jego harmonia i jego trwałość w bycie. W odróżnieniu od gnostyka i poganina chrześcijanin nie może już czuć się „obcym” na ziemi, jakby żył w świecie, który jest wrogi w stosunku do niego. Przeciwnie, cały ten świat, od nieskończenie wielkiego do nieskończenie małego, jest światem „Pana naszego Jezusa Chrystusa”. Nic nie jest pozbawione Jego ciepła, jak nic nie jest pozbawione słońca. W ten sposób znaczenie Chrystusa osiągnęło największy możliwy zasięg. Refleksja nowożytna właściwie nie mogła nic do niego dodać i wszelkie dzisiejsze propozycje szukania „Chrystusa kosmicznego" mają już swoją prehistorię u Ojców Kościoła, a u św. Maksyma Wyznawcy osiągnęły one niezrównaną syntezę ${ }^{17}$.

\section{SYNTEZA I SOBORU NICEJSKIEGO}

Zaprezentowana tutaj synteza pokazuje, że zachodzi ścisła relacja między wizją teologiczno-duchową zaproponowaną przez Ojców Kościoła, której synteza została zapisana w dogmatycznej definicji I Soboru Nicejskiego. Zdefiniowanie Słowa jako „współistotnego Ojcu” oznaczało usytuowanie Go na takim poziomie, że nic nie mogło pozostać poza zasięgiem Jego działania. Jezus Chrystus, jako Współistotny, obejmuje sobą wszystko: całego człowieka, kazdego człowieka i cały jego świat. To wszechobejmowanie zostało jednak zagwarantowane przez zakorzenienie ,znaczenia” Jezusa Chrystusa w samym fundamencie, w którym został zakorzeniony Jego „byt”, to znaczy „w Ojcu”. Tutaj można jasno zauważyć intencję „religijną”, która ukrywa się pod sformułowaniami metafizycznymi, dotyczącymi Jezusa Chrystusa. Jezus Chrystus chciałoby się powiedzieć - nie stanowi w historii i we wszechświecie drugiej antagonistycznej obecności, czy też obecności „dodanej”, w stosunku do obecności Boga. Jest obecnością samego Boga i manifestacją Jego znaczenia dla człowieka. „Ojciec przez swoje Słowo prowadzi i podtrzymuje świat”, jak mówił św. Atanazy. W Nim więc jest obecny byt i znaczenie Boga, który uobecnia się dla człowieka i dla świata; nie jest jednym z wielu „pośredni-

\footnotetext{
16 Athanasius, Contra gentes 41, SCh 18bis, 188-190, tłum. M. Wojciechowski, PSP 62, 68-69.

17 Por. A. Riou, Le Monde et l'Église selon Maxime le Confesseur, Paris 1973.
} 
ków", których pośredniczenie zamyka się w granicach tego świata. Takie jest sens współistotności nicejskiej.

Nie zrozumiało się niczego z homoousios, gdy uważa się, że uznanie pełnej boskości i preegzystencji Słowa może wprowadzić w Bogu „mityczną koncepcję teo-dramatu recytowanego przez dwie, czy nawet trzy, postacie Boże" ${ }^{18}$. Koncepcją mityczną, przeciwnie, była koncepcja Ariusza (i tych, którzy dzisiaj mówią o „boskości stającej się Synem”), skoro obydwie wprowadzają rzeczywistość pośredniczącą między Bogiem i stworzeniem, sytuując ją tylko po stronie stworzenia. Nie była taką koncepcja nicejska, która jest być może bardziej „demitologizującą” niż kiedykolwiek została pomyślana przez teologie chrześcijańskie i niechrześcijańskie.

Pytanie, które spontanicznie pojawia się w tym miejscu jest następujące: $\mathrm{Na}$ czym opierają się te tak bezpośrednie stwierdzenia dotyczące Jezusa Chrystusa? Są wyrazem jakiejś ograniczonej opcji teologicznej, czy też to, co wyrażają jest „prawdą"? Odpowiedź wymaga sięgnięcia do podstawowego problemu wiary. Teologowie chrześcijańscy zaczerpnęli to wszystko z Objawienia i doświadczyli tego wszystkiego, jako koniecznej konsekwencji ich wiary. Innymi słowy, Jezus Chrystus zdobył ten niezwykły zasięg znaczeniowy w oparciu o miejsce, jakie zajął w wierze wspólnoty i w sercach wierzących. Spójność wewnętrzna wiary domaga sie teraz tego uniwersalnego i kosmicznego obrazu Jezusa Chrystusa. „Prawda” tego obrazu ma więc takie same gwarancje, które ma reszta wiary, to znaczy daje wszelką ,gwarancję" temu, kto wierzy, i nie daje „żadnej” gwarancji temu, kto nie wierzy. Chrześcijanin, który chce być spójny, musi jednak wiedzieć, że nie może tworzyć dla siebie Chrystusa różnego, na zredukowaną i własną miarę, pod żadnym pretekstem.

\section{LA PERSONA DI GESÙ CRISTO E IL SUO SIGNIFICATO UNIVERSALE LA PROSPETTIVA PATRISTICA}

(Riassunto)

Il merito principale dei Padri della Chiesa consiste nell'aver elaborato i concetti fondamentali e i principi fondanti della dottrina di fede. In modo particolare, tale contributo va valorizzato nella cristologia perché rimane significatvo e valido anche per le ricerche odierne in questo ambito teologico. La cristologia si fonda sui tre principi. 1. Cristo è Salvatore di tutto l'uomo. La sua incarnazione garantisce la salvezza di tutto l'essere umano (corpo, anima, intelletto, volontà, sentimento),

${ }^{18}$ H. Küng, Essere cristiani, Milano 1976, 502. 
poiché Egli è vero uomo. La cristologia patristica segue il principio: „Il Verbo di di Dio si fece uomo, perché l'uomo diventasse dio". 2. Cristo è Salvatore di tutti gli uomini. L'universalità della salvezza è garantita dall'assunzione dal Verbo della natura umana comune a tutte le persone. Egli si è unito in qualche modo ad ogni uomo. 3. La salvezza di Cristo ha anche una dimensione cosmica in quanto Lui è la pienezza della verità di cui i germi si trovano in ogni creatura (Giustino Martire) e in Lui vengono ricapitolate tutte le cose (Ireneo di Lyone). Questi tre principi si fondano sull'ontologia del mistero di Gesù Cristo, ma, al tempo stesso, mantengono un forte e realistico carattere soteriologico. Anzi, il loro fondamento ontologico è garante della validità e dell'universalità della soteriologia. In questo senso, la cristologia dei Padri non conosce l'antinomia tra ontologia e soteriologia di cui si è tanto parlato nella riflessione cristologica del XX secolo. La cristologia patristica rimane attuale e istruttiva nella sua struttura fondante, indicando come presentare organicamente il mistero di Gesù Cristo, vero Dio e vero uomo. 